\title{
The Effect of Apples as Self-Cleansing to Reduce Plaque Scores on Madrasah Ibtidaiyah Tarbiyah Islamiyah Students Palembang
}

\author{
$1^{\text {st }}$ Listrianah \\ Poltekkes Kemenkes Palembang \\ Palembang, Indonesia \\ listrianah@yahoo.com
}

\author{
$2^{\text {nd }}$ R.A Zainur \\ Poltekkes Kemenkes Palembang \\ Palembang, Indonesia \\ razainur1959@gamil.com
}

\author{
$3^{\text {rd }}$ Andre Trawijaya \\ Poltekkes Kemenkes Palembang \\ Palembang, Indonesia \\ andreysastrawijaya@gamil.com
}

\author{
$4^{\text {th }}$ Septi Alifa Cahyati \\ Poltekkes Kemenkes Palembang \\ Palembang, Indonesia \\ septi_alifacahyati@gmail.com
}

Corresponding author: listrianah@yahoo.com

\begin{abstract}
Plaque is a soft deposit that is tightly attached to the surface of a tooth consisting of microorganisms that multiply in an intercellular matrix when someone neglects the cleanliness of their teeth and mouth. Plaque can be cleaned mechanically or chemically. One of the ways to clean plaque is by consuming apple because it contains tannins which are as astringent and as antiseptic. Through the fiber content that can clean the remaining dental plaque by biting and chewingthe apple, itcan make the apple having the power of self-cleansing. This study aims to analyze the effect of apples as selfcleansing to reduce plaque scoreson Madrasah Ibtidaiyah Tarbiyah Islamiyah students Palembang. The method used in this study isan analytic survey method. There were 60 people used as the samples which consisting of 30 people consuming apples as the intervention group and 30 people not consuming apples as the control group with the total population of the school is 189 people. The sampleswere taken from the non-random population by using the Purposive Sampling Techniquewhich based on a particular consideration made by the researcher after the characteristics of the population have been known. This study shows that the criteria after consuming apples with good categories are 28 people $(93.3 \%)$ while the criteria after not consuming apples with good categories are 11 people $(36.7 \%)$.In short, consuming apples is better than not consuming apples after eating a main course. The result of Chi- Square test and Kolmogorov Smirnov $Z$ test are $p=0,000$. We can conclude that there is a significant effect $(p<0.05)$ of consuming apples to reduce plaque scores.
\end{abstract}

Keywords: Consuming apples, plaque Scores.

\section{INTRODUCTION}

The problem of dental and oral health is a crucial concern and takes effect on health development. Reference [1] said that an important factor that determines the quality of human resources is health. In this case, the groups that are usually vulnerable to dental health disorders are school-age children which a timefor the children to lay a solid foundation so that they can be better human beings in quality.

Tooth and mouth diseases that are mostly suffered by Indonesian people are gingivitis and dental caries. The source of both diseases is the result of neglecting the dental and oral hygiene so that the plaque accumulation occurs. Dental plaque is a soft deposit that is firmly attached to the tooth surface consisting of microorganisms that multiply in the intercellular matrix if someone neglects the cleanliness of their teeth and mouth. Dental plaque cannot be cleaned only by rinse or water spray,it can only be cleaned completely by mechanical ways [2].

Based on basic health research (RISKESDAS) in 2013, $19.5 \%$ of the population in South Sumatera Province had dental and mouth problems, in children aged 5-9 years by $28.9 \%$ and in children aged $10-14$ years by $25.2 \%$. The DMFT index in the South Sumatera Province was 5.3 and it is higher than Indonesia's DMFT that is 4.6 [3].

Prevention efforts in children are needed to overcome dental caries and this must be done systematically and as early as possible at a young age. Ages 8-10 years 
are the age group that is critical for dental caries and has a special characteristic that is the transition of baby teeth to permanent teeth. The prevalence of dental caries in children aged 8-10 years reaches 60-85\% [4]. Chewing fibrous foods such as fruits can help cleaning the teeth. Papaya, pineapple, watermelon, apple, yam, red guava are examples of fruits that are easily found and can be directly consumed in fresh condition. There are several kinds of fibrous and watery foods that can be obtained in the market such as fruits. Another thing about fruit is its ability to be able to perform selfcleansing of the oral cavity.

The fiber and water content of apples can stimulate the speed of salivary secretion and can neutralize acidic substances. Apples also contain tannins which are as astringent and as antiseptic. Tannins also help inhibit the growth of bacteria in the teeth so that it inhibits the growth of plaque that causes dental caries and gum disease. Consuming apples after eating a main course has an ability to clean teeth and mouth which can inhibit the formation of dental plaque, so this fruit is often called as a fruit that has the power to clean teeth or self-cleansing [5]. The purpose of this study is to analyze the effect of apples as self- cleansing to reduce plaque scores on Madrasah Ibtidaiyah Tarbiyah Islamiyah students Palembang in 2018.

\section{Hypothesis}

$\mathrm{Ha}=\mathrm{It}$ is effective to consume apples as self-cleansing on plaque score reduction on Madrasah Ibtidaiyah Tarbiyah Islamiyah students Palembang.

Ho $=$ It is not effective to consume apples as selfcleansing on plaque score reduction on Madrasah Ibtidaiyah Tarbiyah Islamiyah students Palembang.

\section{RESEARCH METHODOLOGY}

The type of research used in this study is an analytic survey that is a research method that tries to explore how and why health phenomena occur and then conduct a dynamic analysis of the correlation among phenomena or between risk factors and effect factors. The time approach used in this study is cross-sectional in which this study involves measuring and observing at the same time between the independent variable and the dependent variable [6].The research was carried out at Madrasah Ibtidaiyah Tarbiyah Islamiyah Cempaka Foundation in Palembang on May 2018. The total population of the school is 189 students.

The samples are taken based on the L.R Gay formula which states that 30 subjects for research on the correlation and 30 subjects on comparative causal. Therefore, the researchers divided the samples into 2 groups, i.e. 30 people consuming apples and 30 people not consuming apples. So, the total number of the samples is 60 people.

For the type of samples, this study uses a Non-Random Sampling with the Purposive Sampling technique which based on a particular consideration made by the researcher after the characteristics of the population have been known [6]. The samples are selected with some criteria, e.i. willing to be the subject of the research, the composition of teeth that are still complete and orderlyor mild dental crowding, not brushingtheir teeth before going to school, having 6 teeth $(16,11,26,36,31,46)$ that represent each segment of plaque measurement.

\section{A. Variable}

1. Independent variable: The independent variables are divided into 2 groups:

a. Group I:respondents consume apples

b. Group II: respondents do not consume apples

2. Dependent variable: Plaque Score Reduction

\section{B. Tools and Materials}

Research tools and materials that are used for data collection in this study arePPE (Personal Protection Equipment), basic instruments (sonde, excavator, tweezers, and windshield), Nier bekken, sputum bucket, cotton pellet, gargle glass, gargle water, disclosing solution, alcohol $75 \%$, pens, and the assessment sheet of plaque scores.

\section{Procedure}

Research Implementation: after the respondents filled their identity, all respondents had snacks with the same menu, and then all of respondent's teeth were smeared with disclosing solution, after all respondents were given disclosing to check the plaque score before consuming apples. After all respondents were given disclosing and checked their plaque scores, then the respondents of group I were given apples weighing 100 grams but the respondents of group II were not. After the respondents of group I consumed apples and group II did not consume apples, all respondents from both groups were checked their plaque scores again.

\section{Checking Up the Respondents}

The plaque scores were calculated by examining the facial or lingual of the dental crowns which divided each surface of the crown into five subdivisions, i.e. D (Distal), $\mathrm{G}$ (one-third of the middle gingiva), $\mathrm{M}$ (Mesial), C (one-third of the middle),I/O (one-third of the middle/Incisal or Occlusal). 
Fig. 1. Five subdivisions of the tooth surface in the plaque index (source: Putri, et al. 2015)

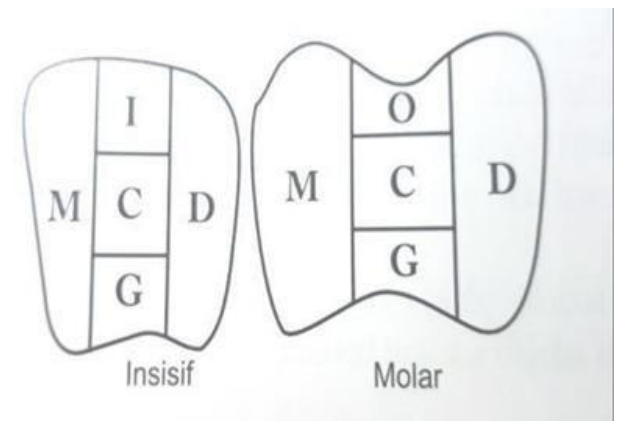

How to assess the plaque is as follows.

Score $0=$ there is no plaque

Score $1=$ there is a plaque

The measurement method to determine the PHP plaque index uses the formula below and the resulting score is in the form of numbers.

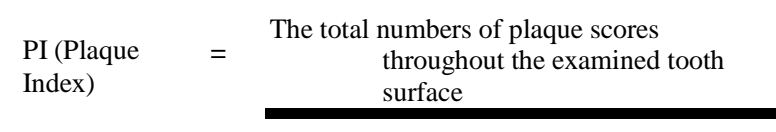

The total numbers of examined teeth

The assessment criteria of oral hygiene level based on PHP (Personal Hygiene Performance) plaque index, i.e.:

Table 1. The Assessment Criteria of PHP

\begin{tabular}{ll}
\hline Criteria & Score \\
\hline Very Good & 0 \\
\hline Good & $0.1-1.7$ \\
\hline Average & $1.8-3.4$ \\
\hline Bad & $3.5-5$ \\
\hline
\end{tabular}

\section{E. Data analysis}

To analyze the obtained data, the following analysis is performed using Univariate Analysis: Which conducted on variables from the results of the study. This analysis only gives the averages distribution and the percentages of each variable. Bivariate Analysis: An analysis that conducted on the two researched variables using Kolmogorov Smirnov Z Chi- Square Test to find.

\section{RESULTS}

Table II. Distribution Frequency of the number of initial and final Plaque scores that consume Apples and the number of Initial and final Plaque scores that do not consume Apples

\begin{tabular}{|c|c|c|c|c|c|c|c|c|}
\hline \multirow{3}{*}{ Criteria } & \multicolumn{8}{|c|}{ Plaque Scores } \\
\hline & \multicolumn{3}{|c|}{ Before } & \multicolumn{4}{|c|}{ After } & \multirow[b]{2}{*}{ Total } \\
\hline & Good & Average & Bad & Total & Good & Average & Bad & \\
\hline \multirow[t]{2}{*}{$\begin{array}{l}\text { Consumi } \\
\text { ng Apples }\end{array}$} & 3 & 23 & 4 & 30 & 28 & 2 & 0 & 30 \\
\hline & $10 \%$ & $76,6 \%$ & $13,3 \%$ & $100 \%$ & $93,3 \%$ & $2 \%$ & $0 \%$ & $100 \%$ \\
\hline \multirow[t]{2}{*}{$\begin{array}{l}\text { Not } \\
\text { Consumi } \\
\text { ng Apples }\end{array}$} & 5 & 19 & 6 & 30 & 11 & 19 & 0 & 30 \\
\hline & $16,7 \%$ & $63,3 \%$ & $20 \%$ & $100 \%$ & $36,7 \%$ & $63,3 \%$ & $0 \%$ & $100 \%$ \\
\hline
\end{tabular}

The table above shows that the plaque scores in the good category in children who consumed apples is 28 people $(93.3 \%)$, while the plaque score in the good category in children who did not consume apples is 11 people $(36.6 \%)$.

The result of Kolmogorov Smirnov test on the results of the plaque index examination shows that the value of $p=0.000$, which means that there is a significant effect $(\mathrm{p}<0.05)$ of consuming apples to reduce plaque scores.

Table 3. The Analysis of Effect of Apples As Self-Cleansing To Reduce Plaque Scores On Madrasah Ibtidaiyah Tarbiyah Islamiah Students Palembang Using Chi-Square with Kolmogorov Smirnov Ztest

\begin{tabular}{lcc}
\hline Chi Square & & \\
\hline & $X^{2}$ & Asymp.Sig. (2- sided) \\
\hline Plaque score & 2,195 & 0,000 \\
\hline
\end{tabular}

The result of the Chi-Square test on the index plaque value shows that the value of $\mathrm{X}^{2}$ is 2.195 with the value of $p=0.000(p<0.05)$. From this result, the hypothesis is accepted and it can be stated that there is an effect of consuming apples to reduce plaque scores.

\section{DISCUSSION}

From table 2, it can be concluded that the assessment of dental plaque scores with good criteria can be found more in the treatment group that consumed apples that is 28 people $(93.3 \%)$ compared with the group that did not consume apples that is only 11 
people $(36.7 \%)$. The results of this study are the same as the research conducted by [5] on the Effect of Chewing Apple and Red Guava on the Reduction of Index Debris, which stated that by consuming apples the average index plaque before and after consuming apples has decreased. From table 3, it can be concluded that there is an effect of consuming apples to reduce plaque scores using chi-square with Kolmogorov Smirnov $\mathrm{Z}$ test that is $\mathrm{p}=0,000$, which means that there is a significant effect $(p<0.05)$ of consuming apples to reduce plaque scores. Reference [7], every 100 grams of apples contains about 85 grams of water. The fiber and water contents of apples can stimulate the speed of salivary secretion and can neutralize acidic substances. Apples also contain tannins which are as astringent and as antiseptic. Besided tannins also helps inhibit the growth of bacteria on the teeth so that it inhibits the growth of plaque that causes dental caries and gum disease.

Apples prevent the formation of plaque both mechanically and chemically, which is as a selfcleansing through the fibers which can clean the remaining dental plaque by biting and chewing. Plaque is a soft deposit that is firmly attached to the surface of a tooth consisting of microorganisms that multiply in an intercellular matrix when someone neglects the cleanliness of their teeth and mouth [2].

As an effort to control plaque, plaque can be controlled by mechanical and chemical tools [5]. Similarly, apples that have fiber and contain lots of water can control plaque mechanically and chemically with natural ways. This is in accordance with the statement of Gobler and Bregnaut (1989) taken from [5] that the mechanical effect of fruit is obtained by the friction between the fibers and the tooth surface caused by masticatory movements. While the chemical effect is obtained by the acid content which can stimulate the flow of saliva so that it can help cleaning the bacteria and food debris on the surface of the teeth [8].

From table 4, it can be concluded that there is a significant effect of consuming apples as a selfcleansing to reduce plaque scores. There is a greater reduction in plaque accumulation to those students that consuming apples compared to those who did not consume apples. It is all because apples contain tannins which act as the astringent [9].

\section{CONCLUSION}

Based on the results of the research on apples as selfcleansing to reduce plaque scores on Madrasah Ibtidaiyah Tarbiyah Islamiyah Students Palembang in
2018, it can be concluded that:

1. The plaque scores on Madrasah Ibtidaiyah Tarbiyah Islamiyah students before consuming apples with good criteria are 3 people, with average criteria are 23 people, and with bad criteria are 4 people.

2. The plaque scores on Madrasah Ibtidaiyah Tarbiyah Islamiyah students after consuming apples with good criteria are 28 people, and average are 2 people.

3. There is a significant effect of apples as selfcleansing to reduce plaque scores on Madrasah Ibtidaiyah Tarbiyah Islamiyah students Palembang in 2018.

\section{REFERENCES}

[1] Andani, B D. Efektifitas Mengunyah Buah Semangka(Citrullus Lanatus) dan Buah Melon (Cucumis Melo 1.) sebagai Self-Cleansing Terhadap Penurunan Indeks debris Anak Usia 8-10 Tahun di SD Abadiah Kota Padang. n.d.

[2] Betri D. Efektivitas Mengunyah Buah Semangka (Citrullus Lanatus) dan Buah Melon (Cucumis Melo L.) sebagai SelfCleansing terhadap Penurunan Indeks Debris Anak Usia 8-10 Tahun di SD Adabiah Kota Padang 2017.

[3] Cahyati WH. Papaya (Carica Papaya) Consumtion To Reduce Debris Index Konsumsi Pepaya (Carica Papaya) Dalam Menurunkan Debris Index. Kemas 2013;8:127-36.

[4] Dalimartha S, Andrian F. Khasiat Buah dan Sayur. 2011

[5] Putri, M H. Ilmu Pencegahan Penyakit Jaringan Keras dan Jaringan Pendukung Gigi. 2013.

[6] Notoadmojo S. Metodologi Penelitian Kesehatan. 2012.

[7] Nurhayati S. Hubungan Mengunyah Buah Apel sebagai SelfCleansing effect dengan Debris Index pada Siswa MI Negeri Mulur Kecamatan Bendosari Kabupaten Sukoharjo Tahun 2009. 2010.

[8] Hidayati S, Suyatmi D-3320-1-S (2). pd. Pengaruh Mengunyah Buah Apel dan Jambu Biji Merah terhadap Debris Indeks. J Kesehat Gigi 2016;03:41-6.

[9] Syahrizal S. Swalayan Di Kota Banda Aceh 2016;1:135-40. 